\title{
DEVELOPMENT OF AGRICULTURAL PRODUCER GROUPS IN POLAND - MAZOVIA CASE STUDY
}

\begin{abstract}
Maciej STAWICKI, Department of European Policy and Marketing, Warsaw University of Life Sciences, Nowoursynowska 166, 02 787 Warszawa, Poland, maciej_stawicki@sggw.pl (corresponding author)

Agnieszka WOJEWÓDZKA-WIEWIÓRSKA, Department of European Policy and Marketing, Warsaw University of Life Sciences, Nowoursynowska 166, 02-787 Warszawa, Poland, agnieszka_wojewodzka@sggw.pl

The aim of the paper was to present the development of agricultural producer groups in Mazovia - region in Central Poland with capital of the Voivodeship in Warsaw. Data and literature analysis, interviews and descriptive methods were used. In the first part the authors present theoretical background of cooperation in agriculture based on social capital. The second part presents the main results of the research: the quantitative development of producer groups in the period 2007-2017, the structure of agricultural products produced by the groups and their legal forms. Currently most of groups operate as limited liability companies and co-operatives. Also the main benefits and barriers concerning creation and development of agricultural producer groups were identified. The main barriers were unwillingness to cooperate, mistrust, and high administrative and legal burdens. On the basis of the study - in order to help develop agricultural groups - it is recommended to strengthen social capital in the rural areas (especially important is overcoming mental barriers and development of trust), educate farmers (management, accounting, etc.) and promote good practice. The conclusions of the study may be applicable in countries where producer groups' development is low (as Lithuania).
\end{abstract}

Keywords: Poland, producer groups, rural areas, social capital

\section{INTRODUCTION}

Agriculture in Poland is a very fragmented sector with many small producers, who often are facing problems with finding buyers and negotiating good prices for their products. Therefore, the possibility to cooperate as agricultural producer groups is an important chance to improve sales conditions and improve the profitability of farms. This problem is taken into account in agricultural and rural development policies, where attention is paid to strengthening agricultural producers and supporting the process of their association. An example is the 2007-2013 Rural Development Programme, which offered specific support to agricultural producer groups. A special form of support under the Program was the measure 142 "Agricultural Producer Groups". Under this measure the amount of PLN 755.2 million was spent on the support of agricultural producer groups, the number of beneficiaries was 1285 (ARMA, 2017). The share of these funds in the Rural Development Programme 2007-2013 budget amounted to 2.4\%. Granted assistance was aimed at: adapting to the market requirements of the production process and production of the producers who are members of such groups; joint placing of goods on the market, including preparation for sale, centralization of sales and delivery to wholesale customers and the establishment of common rules on production information, with particular focus on harvest and availability (RDP, 2007). Currently, Rural Development Programme 2014-2020 continues to provide financial support for the development of agricultural producer groups. In Poland, as in many other Central-Eastern European countries the process of forming groups ran slowly despite the available financial support because of low level of social capital among people living in the rural areas. The aim of the paper was to present the development of agricultural producer groups in the best developed and most populated Polish region (Mazovia) in relation to the concept of social capital. Specific objectives include presentation of quantitative and structural development of producer groups, identification of main barriers in establishing cooperation. Also the changes of main legal forms of groups and types of goods produced by cooperating farmers in the period 2007-2017 were presented.

\section{RESEARCH METHODS}

Data and literature analysis, interviews and descriptive methods were used. The research was covered among selected, highly spatially concentrated but not cooperating farmers in Mazovia region, which was selected because despite of its highest area and population - the number of agricultural producer groups puts the region at 6th position in Poland (Guzdek, Petryk, 2016). The analysis was based on data gathered by Mazovia Marshall Office, Ministry of 
Agriculture and Rural Development and Agricultural Market Agency from the years 2007, 2010, 2013 and 2017. The authors interviewed also farmers not being members of agricultural producer groups to identify and verify the most common barriers of cooperation. The field studies were conducted twice: in 2007 and in 2017, using interview questionnaire with questions concerning the main factors and barriers of cooperation. A total of twenty one chosen in a targeted manner respondents cultivating strawberries and growing vegetables under covers (pepper, lettuce, radish) and people involved in agricultural trade were interviewed. Another objective of the study was to verify the outcomes of other studies, which showed that the main barriers in creating groups were mentality problems, weak economic condition of farms, administrative problems and unsatisfactory help of local governments for producers (Kutkowska, Antosz, 2012).

\section{SOCIAL CAPITAL AND COOPERATION IN RURAL AREAS}

Social capital means the ability of people to work together for common purposes in groups or to join in a group to accomplish a goal (Fukuyama, 1997). The basis for effective cooperation is the informal rules that exist between the members of the group, the norms and beliefs that determine the level of self-organization and self-management. The idea of social capital is interesting for representatives of various disciplines, including economists. The main function of social capital is to reduce the uncertainty of action in social and economic life, which makes it possible to find in the social capital the origin of economic rationality. It is a modern, endogenous factor of socio-economic development, increasing the efficiency of using hard development factors (Antoci, Sabatini, Sodini 2009). This form of capital, embodied in repetitive interactions, solves many problems of economic life, allows the individual to predict the behaviour of other people, which facilitates decision making. Literature presents various types of social capital (Nahapiet, Ghoshal, 1998; Grootaert, Bastelaer, 2002). According to Grootaert, Bastelaer (2002), the following components of social capital can be distinguished: structural and cognitive. The structural dimension encompasses collective action, social organizations, social networks, groups and structures. It refers to all state and local institutions operating in a given area such as foundations or associations. Cognitive social capital refers to shared norms, values, trust, attitudes and beliefs. In practice both dimensions complement one another. In this study the focus is on the structural dimension based on a personal cognitive bond.

Depending on the types of ties between individuals (Putnam, 2000; Woolcock, 2001; Hawkins, Maurer, 2010) we can talk also about bonding capital (with strong family and neighbourly ties), bridging capital (with ties with individuals other than family and neighbours) and linking capital (for interactions between communities from various sectors and tiers of authorities).

The willingness to take collective action and the activity of the inhabitants are influenced by various factors, often specific to the area. This causes the level of social capital to vary between countries or regions. In Poland, the level of social capital is low, and rural areas are characterized by significantly lower level of social capital compared to cities (WojewódzkaWiewiórska, 2015). The analysed Mazovia region belongs to a group of regions with low social capital in rural areas. The low level of self-organization of farmers over recent years has been identified as a key problem in the development of Polish rural areas. Significant historical factors such as the partitions of Poland in the 18th century and communist regime after the Second World War (displacement of the population, collectivization, mandatory deliveries of products) were significant (Perepeczko, 2003). The process of integration in the processing sector was a major factor in the change in self-organization of farmers after 1989. Changes in the market caused large trading companies to require large batches of homogeneous goods from farmers. The fragmented and dispersed agricultural producers were not able to meet these requirements. In reference to the concept of social capital, the benefits of farmers' economic cooperation can be mentioned in the improvement of their market position, the reduction of production costs and the broadly protected protection of their interests in the market.

\section{DEVELOPMENT OF PRODUCER GROUPS}

Agricultural producer groups were introduced to Polish legislation in the year 2000 (Act of 15 September 2000, OJ 2000, No. 88, item. 983), when the new law allowed farmers to organize themselves into groups of agricultural producers. The main objectives were to adapt their agricultural products and production processes to market requirements, allow joint marketing of goods, help the development of business skills, marketing, and to organize and facilitate innovation processes as well as to protect the environment. Farmers can work together in chosen by themselves legal form, i.e.: association, union, cooperative, limited company or a joint stock company.

In the period 2007-2017 the number of registered producer groups in Mazovia region was increasing steadily but faster between 2010 and 2013. It is important to have in mind that the date of group registration does not necessarily mean the date of its creation (Sobczak et al, 2013). In 2007, 21 groups were registered but 15 of them (71\%) were groups of fruit and vegetable producers, which were later classified as fruit and vegetable producer organizations (not registered as agricultural producer groups). This was caused by entry into force of the Regulation of the Minister of Agriculture and Rural Development of 16 December 2008 on prerequisites for the recognition of fruit and vegetable producer groups (Filipiak, 2013). Therefore, at Fig 1. only 6 agricultural producer groups were indicated.

Through analysed years the number of groups changed from 6 to 89 (Fig. 1). Private limited companies (PLC) were developing fastest - there were 25 times more PLC at the end of study period than at the beginning, also high increase in the number of cooperatives was observed (15 times more). On the other hand, the number of producer unions was stable (increase from 1 to 9), and the only association of pork meat producers has figured in the register until 2014. No joint stock company was created, which can be caused by a high initial capital required in this type of company. The dynamics of agricultural producer groups by different product types in Mazovia region in the period 2007-2017 was shown in Fig. 2. The fastest increase was identified among poultry, live poultry and pork and live pig producers. As detailed studies showed, the most important factor for this increase was the financial aid under measure 142: Agricultural 
producer groups in Rural Development Programme for 2007-2013, what was highlighted in other studies (Lemanowicz, 2005; Krotowska, 2012). After 2014 the aid is available only for new established groups which members have not been members of any group before, what makes the increase in number of groups slower in the last years.

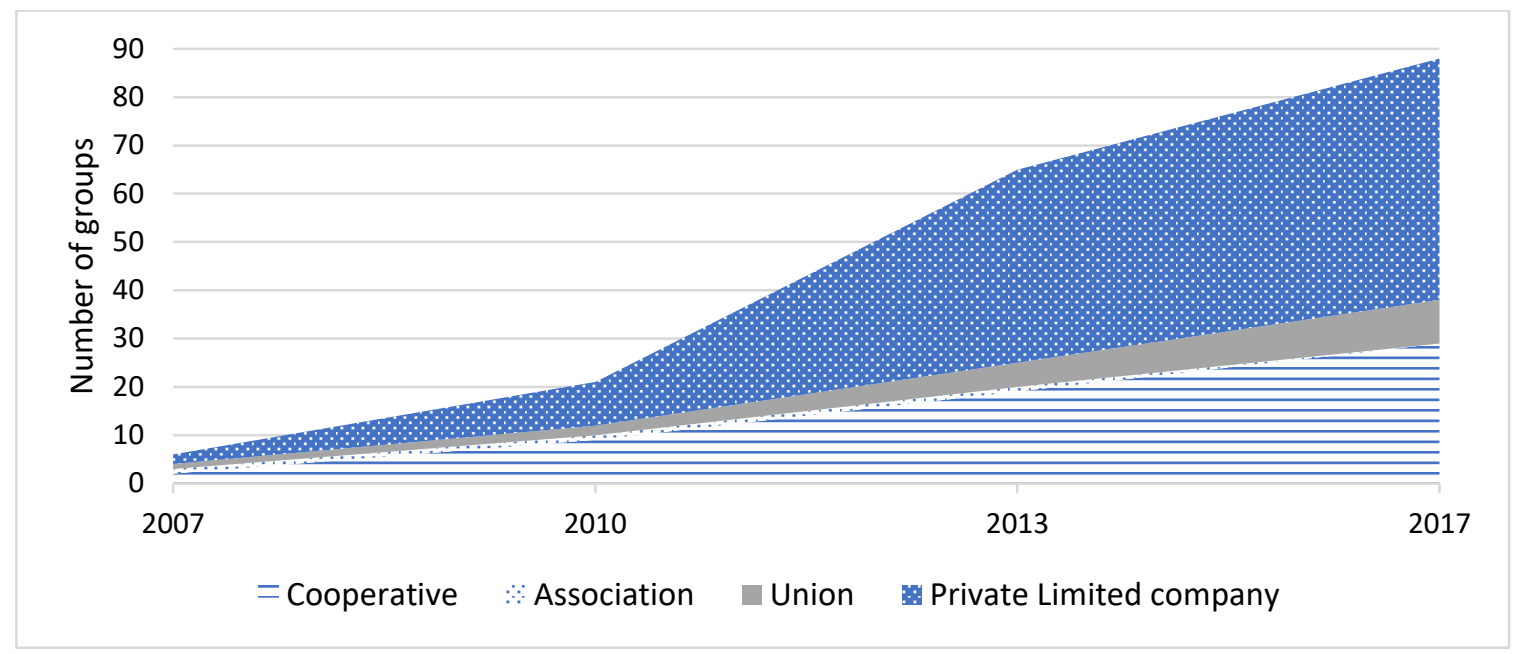

Authors' elaboration based on data of Mazovia Marshall Office and Agricultural Market Agency 2007, 2010, 2013, 2017

Figure 1. The number and legal forms of agricultural producer groups in Mazovia region in the period 2007-2017

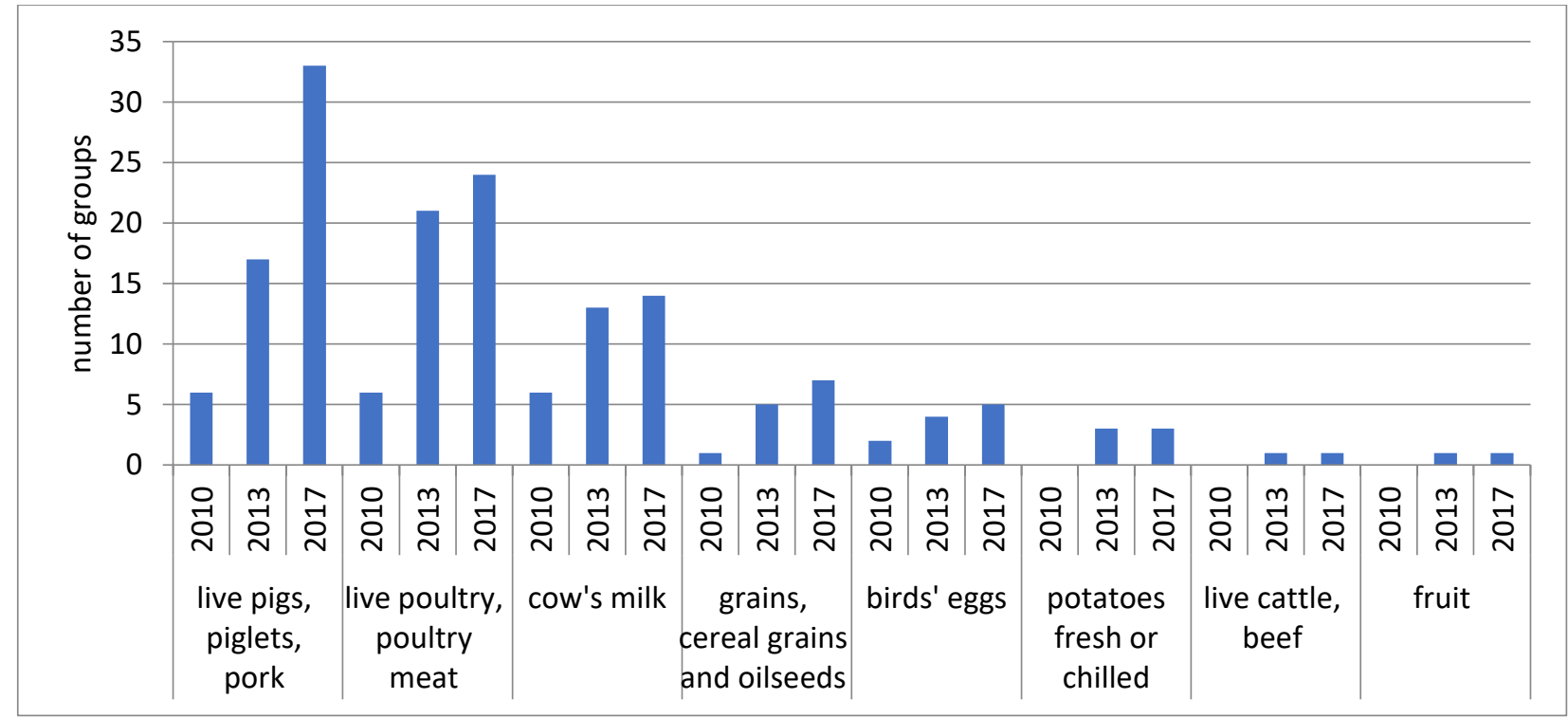

Authors' elaboration based on data of Mazovia Marshall Office and Agricultural Market Agency 2007, 2010, 2013, 2017

Figure 2. The dynamics of agricultural producer groups by different product types in Mazovia region in the period 2007-2017

The detailed structure of agricultural products produced by the groups and their legal forms in the period 20102017 were presented in Fig. 3-5. In 2010 producers of only 5 groups of products were functioning as 21 producer groups. Interestingly, dairy cattle and grain farmers formed only cooperatives, while poultry producers and poultry for eggs breeders operated only as limited companies.

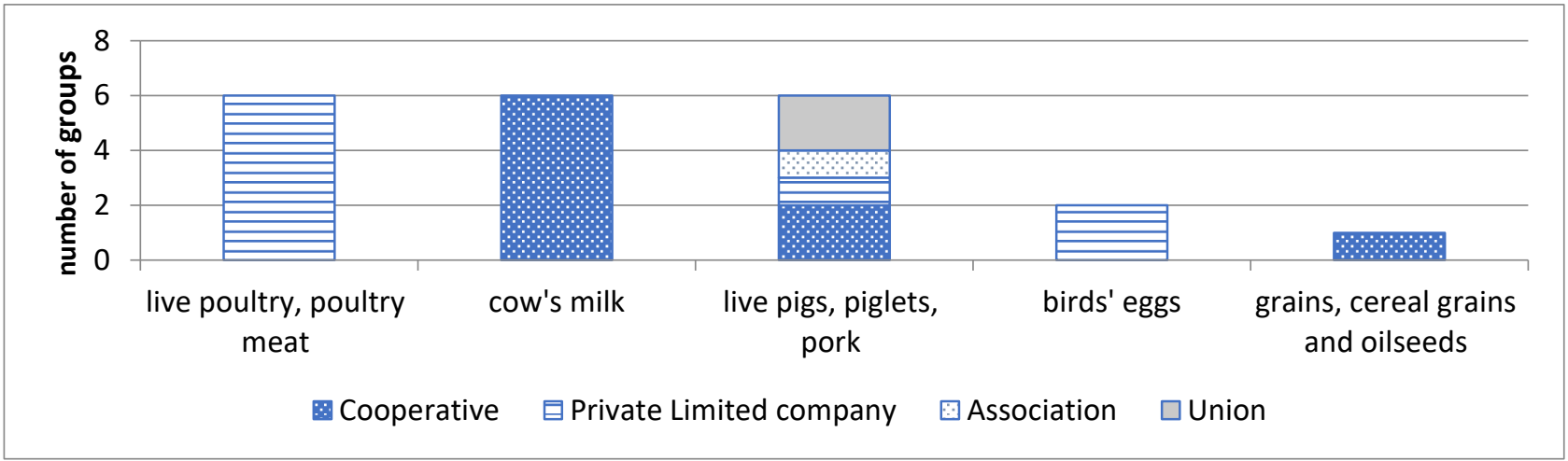

Authors' elaboration based on data of Ministry of Agriculture and Rural Development, 2010

Figure 3. The number of agricultural producer groups by product in Mazovia region (2010) 
Later on also farmers producing other goods (potatoes, beef, fruit) started setting up producer groups. The most common form of cooperation in nearly all groups of producers remained limited companies, more than 5 cooperatives were functioning only among milk and pork producers. Cooperation in the form of agricultural groups has developed best among meat producers - half of all groups were established by poultry, pork and live poultry and live pig producers. Another group of highly organized farmers are milk producers, whom the producer group helps provide group members with good market prices.

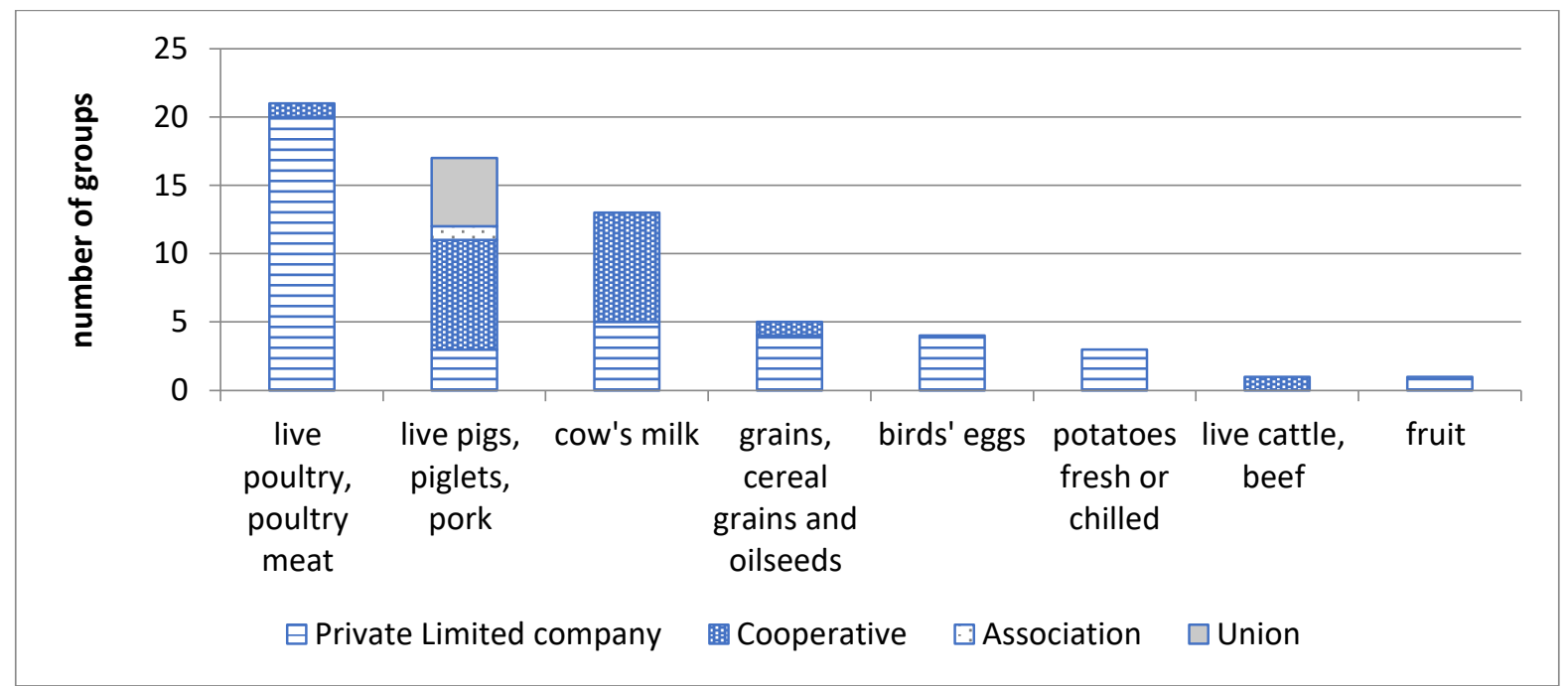

Authors' elaboration based on data of Ministry of Agriculture and Rural Development, 2013

Figure 4. The number of agricultural producer groups by product in Mazovia region (2013)

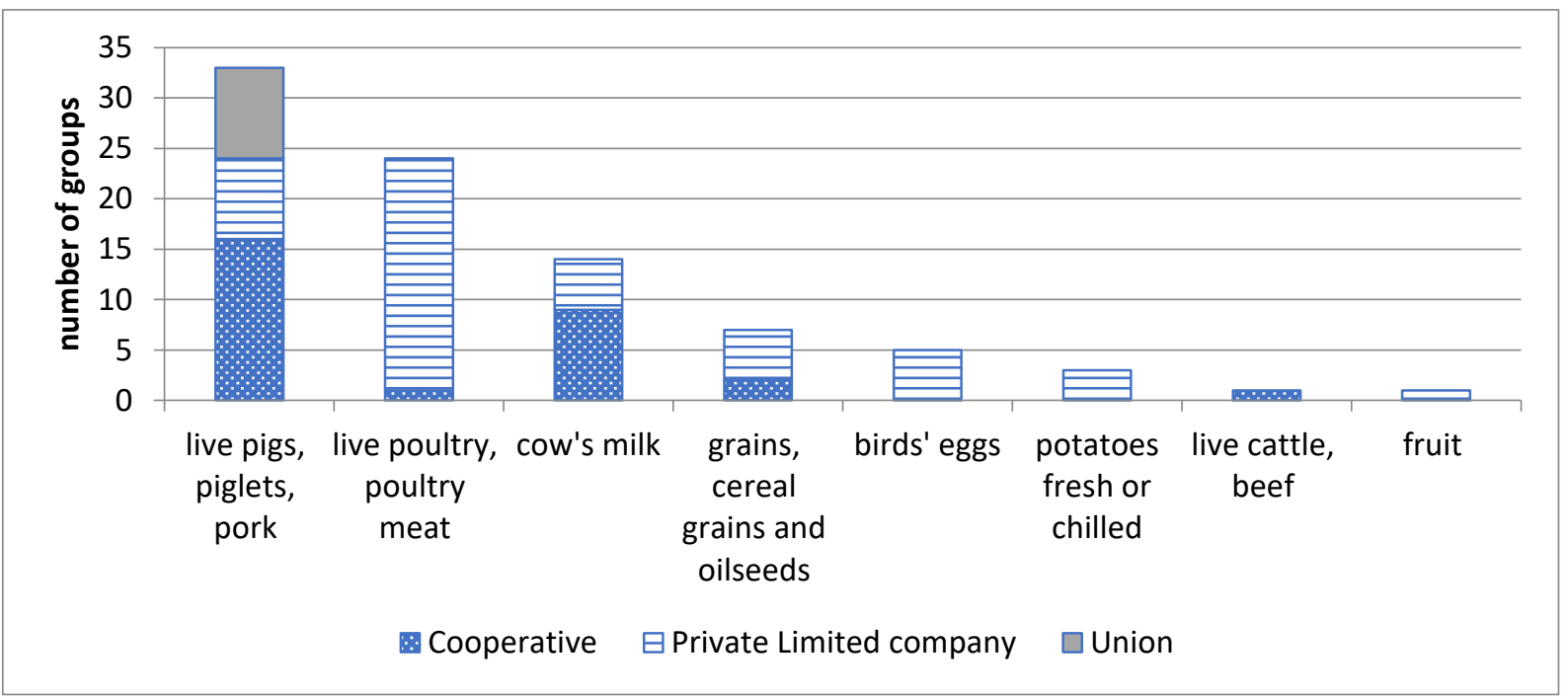

Authors' elaboration based on data of Agricultural Market Agency, 2017

Figure 5. The number of agricultural producer groups by product in Mazovia region (2017)

In comparison to the structure of groups by products in Poland, the share of poultry producers is 2.5 times higher and pork and milk producers is twice higher in Mazovia region. The reason for this is an existing high concentration of poultry producers in the north-western part of the region and high proportion of meadows and pastures in north-eastern part of the voivodeship.

\section{BARRIERS IN CREATION OF PRODUCER GROUPS}

Surveys conducted in 2007 and 2017 with selected, not cooperating farmers allowed to identify the main barriers concerning creation and development of agricultural producer groups. The lack of mutual trust between manufacturers is one of the most important factors stopping cooperation. Among some farmers exist a strong unwillingness to cooperate and lack of understanding of benefits from working together, as was also found in other studies (MARD, 2014; Adamowicz, 2007). This is strictly connected with low level of social capital in the rural areas. Some respondents also stressed the problem of distrust of financial settlements within the group and problem of delayed payment for the sale of products through the group. Another barrier is mentality - in search for a better price farmers themselves are looking for buyers instead of selling products by a group representative. On the other hand, the interviews showed that sufficient profitability of production in individual farms is the reason for lack of economic incentive for creating producer 
associations. Interviews in 2017 showed that some farmers established long-term relationships with their customers, who buy the goods directly from them. Other barriers can be called psychological, they were: fear of engagement and distinction from the environment, lack of confidence in one's own strengths. The last group of barriers is connected with insufficient financial education, no ability to run a business and lack of adequate management skills. Last identified obstacle was higher administrative and legal burden and the need to keep accounting records (some farmers fear to disclose their revenue).

\section{RECOMMENDATIONS}

On the basis of the study - in order to help develop agricultural groups - it is recommended to strengthen social capital in the rural areas, its cognitive dimension (especially important is overcoming mental barriers and development of trust), educate farmers (management, accounting, etc.) and promote good practice. Stimulating co-operation can also be achieved by identifying examples of good practices and the benefits of synergies, creating information and knowledge sharing platform, publishing materials promoting cooperation what can help facilitating contacts between manufacturers. Pilot networking projects can be used to encourage farmers to set up cooperation. Creation of advisory points for groups or indication of authority (researcher, local leader, manager) could also convince people to the idea of collaboration. Another important actions should be education of business management, accountancy, foreign languages, and marketing.

\section{CONCLUSIONS}

The analysis conducted in Mazovia can lead to the following conclusions:

1. Between 2007 and 2017 the number of agricultural producer groups has been developing fast in the analysed region. Currently most of groups operate as limited liability companies and co-operatives. Cooperation in the form of agricultural groups has developed best among meat (poultry, pork) producers. Another group of highly organized farmers in Mazovia are milk producers. This is reflected in a very dynamic increase in the number of entities in both groups.

2. The main barriers of cooperation among farmers can be divided into 3 groups: administrative, economic and personal - connected with social capital and psychological features. The main personal barriers to group formation is the mentality of farmers, their reluctance to cooperate due to lack of trust. Sufficient profitability of production in individual farms is a common reason for lack of economic incentive for creating producer associations. Psychological barriers were fear of engagement and lack of confidence in one's own strengths. Higher administrative and legal burdens are an important obstacle, too.

3. Strengthening social capital, especially in the cognitive dimension, is the most important action that may help overcome mental barriers in order to develop cooperation in the rural areas. It is necessary for the emergence of new groups of agricultural producers, and the existing ones have already gained a better position in the market and have had better management results. It is important to realize that this is a long-term process, as confirmed by the example of the Mazovia region, where there are slow changes in cooperation in the analyzed period.

The conclusions of the study may be applicable in countries where producer groups' development is still low, especially in countries where the determinants of the development of social capital were similar.

\section{REFERENCES}

1. Adamowicz, M. (ed.), 2007. Uwarunkowania rozwoju gron przedsiębiorczości w agrobiznesie na Mazowszu (Conditions of Enterepreneurship Clusters Development in Agribusiness in Mazovia), Publishing House WULS, Warsaw. [In Polish]

2. Agency for Restructuring and Modernization of Agriculture (ARMA) data. 2017. Data on the implementation of RDP 2007-2013 activities, (31 Dec 2015).

3. Agricultural Market Agency, Rejestr grup producentów rolnych, (Registry of agricultural producer groups) http://www.arr.gov.pl/data/02101/rgpr ot warszawa 31082017.pdf (Accessed: 12/09/2017)

4. Antoci ,A., Sabatini, F., Sodini, M., 2009, Fragility of Social Capital, University of Siena, pp. 1-8

5. Filipiak, T., 2013. Grupy producentów owoców i warzyw w Polsce, (Producers groups of fruit and vegetables in Poland). Roczniki Naukowe SERiA, Vol. XV, Iss. 6, pp. 69-75. [In Polish]

6. Fukuyama, F. 1997. Trust. Social capital and the way to prosperity, PWN, Warsaw-Wroclaw.

7. Grootaert, Ch., Bastelaer, Th. van. 2002. Introduction and overview, [in:] Grootaert, Ch. Bastelaer, Th. Van. The Role of Social Capital in Development. An Empirical Assessment. Cambridge University Press, pp. 1-15. https://doi.org/10.1017/CBO9780511492600.002

8. Guzdek S., Petryk A., 2016. Cooperation of agricultural producers in Poland. Geomatics, Landmanagement and Landscape, No. 4, pp. 89-100.

9. Hawkins, R., Maurer, K. 2010. Bonding, Bridging and Linking: How Social Capital Operated in New Orleans following Hurricane Katrina. British Journal of Social Work, Vol. 40, pp. 1777-1793. https://doi.org/10.1093/bjsw/bcp087

10. Krotowska, M. Wspieranie tworzenia grup producentów rolnych i ich związków w świetle badań (Supporting the creation of groups of agricultural producers and their results in the light of research). Roczniki Naukowe SERiA, Vol.. XIV, Iss. 3, pp. 213-2017. [In Polish] 
11. Kutkowska B., Antosz I., 2012. Szanse i zagrożenia rozwoju grup producentów rolnych (Opportunities and Threats of Agricultural Producer Groups Development). Wieś i Rolnictwo, No. 4, pp. 91-111. [In Polish]

12. Lemanowicz, M. 2005. Organizacje i grupy producentów szansą na poprawę konkurencyjności polskiego rolnictwa (Organizations and producer groups are an opportunity to improve the competitiveness of Polish agriculture), Publishing House WULS, Warsaw. [In Polish]

13. Mazovia Marshall Office, Wykazy grup producentów rolnych na terenie województwa mazowieckiego z lat 2007, 2010, 2013, (Registry of agricultural producer groups in Mazovia voivodeship 2007, 2010, 2013). [In Polish]

14. Ministry of Agriculture and Rural Development (MARD), 2014. Ocena efektów wsparcia udzielonego w ramach działania $142-$ „Grupy producentów rolnych” Programu rozwoju obszarów wiejskich na lata 2007-2013 (Evaluation of the effects of support granted under measure 142 - "Agricultural Producer Groups" of the Rural Development Program 2007-2013). Warsaw.

15. Nahapiet, J., Ghoshal, S. 1998. Social Capital, Intellectual Capital, and the Organizational Advantage. The Academy of Management Review, Vol. 23, pp. 242-266.

16. Perepeczko, B. 2003. Powojenne uwarunkowania kapitału społecznego współczesnych polskich rolników (Postwar determinants of social capital of contemporary Polish farmers). Wieś i rolnictwo, No 3 (120), pp. 62-71. [In Polish]

17. Putnam, R. 2000. Bowling Alone: The Collapse and Revival of American Community. New York, Simon \& Schuster. https://doi.org/10.1145/358916.361990

18. Rural Development Programme 2007-2013. 2007. MARD, Warsaw.

19. Sobczak W., Jablonska L., Dziedzic A., 2013. Wybrane problemy funkcjonowania grup producentów owoców z regionu grójeckiego i rawskiego (Selected problems of fruit producer groups from the Grójec and Rawa regions). Journal of Agribusiness and Rural Development, Vol. 3(29), pp. 121-131.

20. Ustawa z dnia 15 września 2000 r. o grupach producentów rolnych i ich związkach oraz o zmianie innych ustaw (Act of 15 September 2000 on agricultural producers' groups and their relationships and about the amendment to other acts), OJ 2000, No. 88, item. 983. [In Polish]

21. Wojewódzka-Wiewiórska, A. 2015. Structural Dimension of Social Capital in Poland. Urban Versus Rural Areas. Proceedings of the 7th International Scientific Conference: Rural Development 2015, pp. 1-6, Kaunas, Lithuania, Aleksandras Stulginskis University.

22. Woolcock, M. 2001. The place of social capital in understanding social and economic outcomes. Isuma: Canadian Journal of Policy Research, Vol. 2 (1), pp. 11-17. 